\title{
Teaching Critical Reading Through Online
}

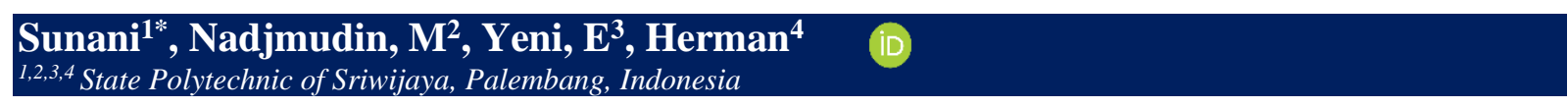

\section{A R T I CLE IN F O}

Article history:

Received November 23, 2020

Revised November 25, 2021

Accepted February 12, 2021

Available online May 25, 2021

Kata Kunci:

Membaca Kritis, Pembelajaran

Online, EFL

\section{Keywords:}

Critical Reading, Online

Learning, EFL

DOI:

http://dx.doi.org/10.23887/jpbi.v9 i1.30012

\section{A B S T R A C T}

The literacy ability of Indonesian children is lower than children in other countries. In addition, students' vocabulary mastery is low. Even though the teacher had given vocabulary instruction to the students during the reading comprehension class, they still translated the text word by word into Indonesian. This study analyzes the effect of online learning on the acquisition of critical reading among students. This study used a pre-experimental study without a control group. Tests for the validity and reliability of reading comprehension texts and vocabulary tests were conducted before the test involving 40 participants. The technique used to collect data is a test. Validity and reliability were measured using some of the same texts used as pre-test and post-test. The pre-test and post-test scores were analyzed by Wilcoxon statistical analysis to test their reading scores before and after the intervention on the same subjects. The findings from the t-test revealed that the critical reading intervention was beneficial for students. Further studies showed that the instructional intervention adopted could help them improve their reading comprehension performance. These findings are expected to provide a teaching model that responds to the typical rise of today's online learning.

This is an open access article under the CC BY-SA license. Copyright @ 2021 by Author. Published by Universitas Pendidikan Ganesha. \begin{abstract}
negara lain. Selain itu, penguasaan kosakata siswa rendah. Meskipun guru telah memberikan instruksi kosakata kepada siswa selama kelas pemahaman membaca, Penelitian ini menganalisis pengaruh pembelajaran online terhadap perolehan membaca kritis di kalangan mahasiswa. Penelitian ini menggunakan penelitian praeksperimen tanpa kelompok control. Uji coba validitas dan reliabilitas teks param bacaan dan tes kosakata telah dilakukan sebelum tes yang melibatkan dan reliabilitas diukur dengan menggunakan beberapa teks yang sama yang digunakan sebagai pre-test dan post-test. Skor pre-test dan post-test dianalisis dengan analisis statistik Wilcoxon untuk menguji skor membaca mereka sebelum sesudah intervensi pada mata pelajaran yang sama. Temuan dari uji mengungkapkan bahwa intervensi membaca kritis bermanfaat bagi siswa. Studi lanjut menunjukkan bahwa intervensi instruksional yang diadopsi dapat membantu mereka meningkatkan kinerja pemahaman bacaan mereka. Temuan ini diharapkan dapat memberikan model pengajaran yang menanggapi kebangkitan khas pembelajaran online saat ini.
\end{abstract}


distance learning or online learning - with institutional collaborations to help provide websites, guidance, and support. Research studies and training must be carried out consistently through the learning process (Kadafi et al., 2021; Rhim \& Han, 2020)

However, the current problem is that teachers use technology in learning (Komalasari \& Rahmat, 2019; Primamukti \& Farozin, 2018). Teachers should use this technological advancement in developing learning media or teaching materials that make it easier for students to learn (Cloonan et al., 2020; Khan \& Masood, 2015). This has an impact on the low ability of students. Based on the results of observations made at the English Department of the Sriwijaya State Polytechnic, it was found that several obstacles in students' reading instructions were still low. The first problem is low vocabulary mastery. Even though the teacher had given vocabulary instruction to the students during the reading comprehension class, they still translated the text word by word into Indonesian. The indicates that they lack strategic practice on how to infer word meaning contextually. The reading task itself is problematic because the given texts rarely stimulate their curiosity or lead them to think more deeply or intensely about the problem of the text. Finally, students lack awareness and control over their reading process or metacognition.

The effective use of information by students has become a must in critical reading (Din, 2020; Lai et al., 2019). Information literacy skills are essential and basic abilities to know what information is required, where to find it, and how to evaluate, use, and communicate it ethically (Heidari, 2020; Moghadam et al., 2021). When students obtain adequate information literacy skills, they can think critically, interpret information, and make informed judgments (Borre et al., 2019; Rubini et al., 2018). Their ability to work independently is therefore improved. People today live in a world with unparalleled access to a vast array of online information and experiences. In addition, it has become possible for anyone to use mobile technologies (e.g., smartphones, cameras, and voice recorders) which enable learning beyond the classroom walls (Anitha Kumari et al., 2020; Fu \& Hwang, 2018). Related research has shown that academic study requires continuous literacy growth. New innovative information technologies, such as social media environments and online communities, challenge traditional definitions of information literacy. Reading proficiency is one of the important tools for acquiring foreign language input, the application of online learning in this skill would be of great help to EFL students (Liao et al., 2018; Shastina et al., 2020; Stover et al., 2016). The methods and technologies and should be disseminated to teachers.

The solution offered is to teach critical reading online. Critical reading is an investigation of, and a critique of, the validity of arguments in reading (Akın et al., 2015; Haromi, 2014). Balanced meaning is entangled in the surface, or face-value meaning of a text can attempt to persuade the reader, either by biased views, unintentional presentation, or even intentionally including factual inaccuracies. It is the task of the critical reader to 'star reading' and perform text analysis to comprehensively understand its whole meaning (Hochweber \& Vieluf, 2018; Memiş \& Kandemir, 2019). Critical reading strategies can motivate readers to face difficult passages and help increase retention for less-skilled readers (Hashimoto et al., 2019; Reilly, 2021). These three critical reading strategies (Talebi \& Marzban, 2015). The first strategy utilized in this study is annotating (Reilly, 2021; Talebi \& Marzban, 2015). This is the strategy the researcher explicitly taught during the reading which is actively reading the text while reading and marking, circling, or writing some keywords, and the meaning of unknown words (synonym and antonym) and the definitions in the margin. By applying this strategy, the learners pay attention to the unknown words and they are not ignoring the unknown words in the text. The learners should also have a pencil in hand so that they can "annotate" their text. The second strategy of this study is inferencing which takes place after guessing. A learner who has been taught guessing strategies would not automatically produce correct guesses while reading. The last strategy is summarizing which helps the learners to self-correct by the means of reading the text, again and again, checking the topic sentences, identifying the main ideas, and relating passages to each other. In this study, the participants first looked for main information while their reading, and then they switched to style, details, and examples in the subsequent readings.

Previous research stated that students need critical thinking skills (Ariani, 2020; Saprudin et al., 2019; Seibert, 2020). Other research findings also state that critical reading is needed by students so that students can understand the contents of the reading correctly (Akin et al., 2015; Reilly, 2021). So it can be concluded that students need critical reading skills. This study aims to analyze the effect of using critical reading strategies on student learning confidence in an online environment. This study attempts to investigate whether online learning significantly affects students' critical reading comprehension.

\section{METHOD}

This study used pre-experimental research without a control group. Pretest and post-test were administered to investigate the effect of learning intervention. The research was conducted in two reading classes at the English Study Program of State Polytechnic of Sriwijaya. Class A and B in the second semester, each having 24 students, participated in a critical reading course using the Internet. 
This study used online learning modules discussing a wide range of topics. The original instructional contents were adapted from several web-based online instructional modules and articles. A description of the intervention is: Students were pretested before the instructional intervention. The test was used to measure the abilities to infer various layers of information from the source texts. The study used the validity and reliability test of Cronbach Alpha, matching the test items with Bloom Taxonomy that were considered sufficient for measuring the subjects' comprehension.

They progressed through the content learning depending on their topics, ranging from Amazing Animals, Events, Technology, Computer, Food and Drinks, Health to Tourist Attraction weekly in 150 minuteonline learnings. In the online reading treatment for ten weeks, all the students received the same information about critical reading strategies more than once; selected strategies related to specific reading objectives and comprehension were repeated in some topics. When students finished reading materials and exercises, they submitted their works on the web page. The participants in this online instructional set were also assigned to demonstrate the use of reading strategies in their video so that the teacher and their peers could view and learn their teachers' feedback. In this study, the students receiving this treatment received language focus related to key learning objectives and critical reading strategies. Some terminologies referred to the names of the graphic organizers.

Three texts about the Komodo dragon were taken from some websites to construct the test instrument for the pre-test and post-test. The try-out for validity and reliability of the reading comprehension texts and vocabulary test had been conducted before the test involving 40 participants. From the source reading texts, paragraphs are immediately followed by comprehension questions and a summarization task. The questions had been designed to represent a variety of comprehension types according to Barrett's Taxonomy. The validity and reliability were measured using the same multiple texts were used as the pre-test and post-test. Then, the texts, academic words, and some more low-frequency but important words are taken and made into a 17-item multiplechoice and summary test. The participants of this quasi-experimental study included 71 students age 18 and older years. $23 \%$ were male and $77 \%$ female. From the data collection procedures, the scores on pre-test and post-test of reading comprehension were obtained to answer the research question. The pre-test and post-test scores were analyzed with Wilcoxon statistic analysis to examine their reading score before and after the intervention on the same subjects.

\section{RESULT AND DISCUSSION}

Result

Based on the content validation calculation using the Cronbach Alpha statistic analysis, it can be concluded that all test items show a correct category, with the lowest coefficient correlation of 0.328 and the highest coefficient of 0.721 . Next, the researchers conducted an interrater reliability test to determine the level of reliability on the instrument of pre and post-test. Interpretation of the reliability coefficients value is high (Guttman split-half Coefficient: 0.825). If the coefficient value is close to 1.00 means, the level of agreement is high. If the index of the agreement is less than 0.4 , then the validity is low, and if more than 0.8 is meant to be very high or meets the criteria of the validity coefficient value $\geq 0.3$. The data for reliability show that the test items are reliable (Guttman split-half Coefficient .825). In contrast, the post-test suggested a significant increase, as shown in the data results obtained using the Wilcoxon Signed Ranks Test on the score variable after the treatment (post-test). The value of the score gained after the treatment differed between values before and after the intervention was given. After being given an instructional intervention, the results of the posttest showed that the majority of respondents enjoyed an increase in their scores gained as a result of online learning. Herewith are the detailed question and analysis results for each question: Question 1: Do you have time allocation for increasing reading ability by online learning?

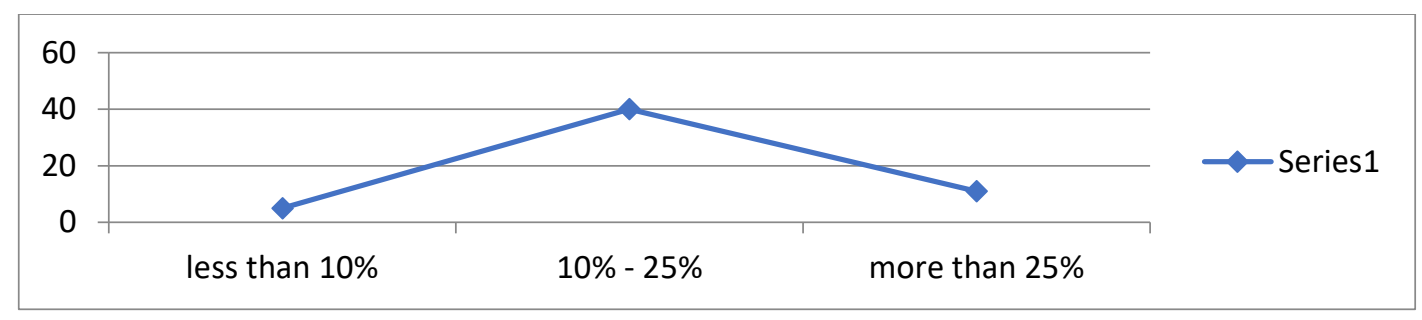

Figure 1. Chart Question 1 
The chart reflects the students' observation about time allocation for increasing reading ability by online learning. 71 students participate in this survey. The finding shows that most students (51 students) perceptions are between $10 \%$ and $25 \%$ of the total amount allocated for reading. Six students mention that listening time allocation is less than $10 \%$ out of the whole English learning time portion. Other 14 students observe that time allocation is more than 25\%. Question 2: Have you ever failed your listening, reading, writing, speaking test?

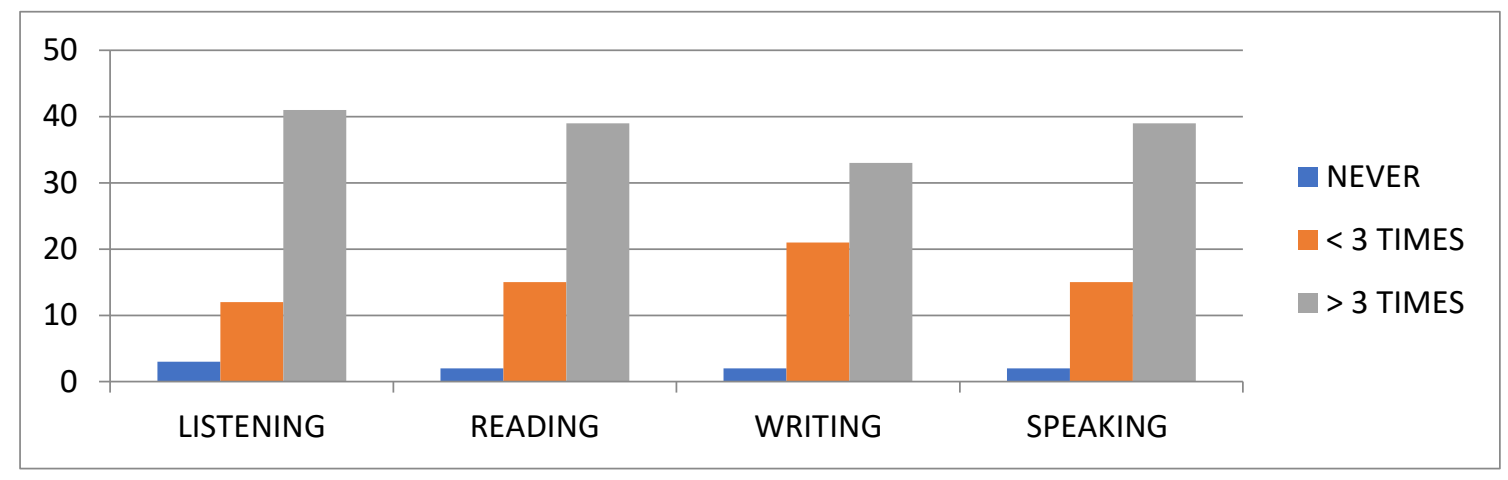

Figure 2. Chart Question 2

Most participants state that they failed four language skills tests. Failure in the listening test is 71 students, 42 students feel they failed in the reading test, 35 students failed in writing, and 40 students failed in speaking test. The students who feel they fail two times in writing 22 students, 15 students fail reading and speaking test. 12 students fail less than 3 times in listening. Two students feel always succeed in reading, writing, and speaking tests. Three students feel always succeed in the listening test. Question 3: How often do you self-study reading at home during online learning?

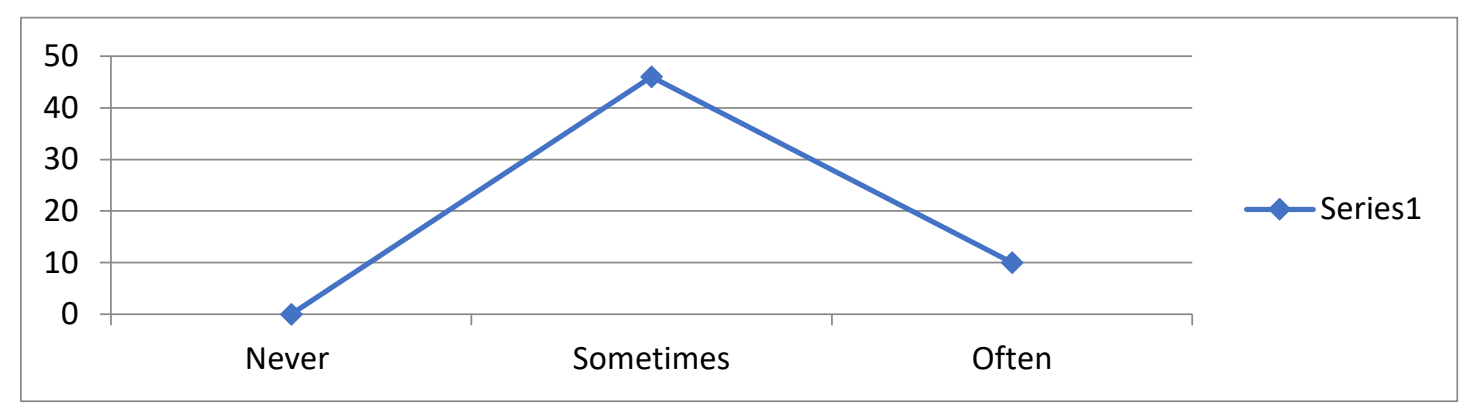

Figure 3. Chart Question 3

This chart shows that students do learning online. 55 students sometimes learn reading by Learning Management System (LMS) Polsri. The other 16 students often do learning reading. Question 4: How do you self-study at home?

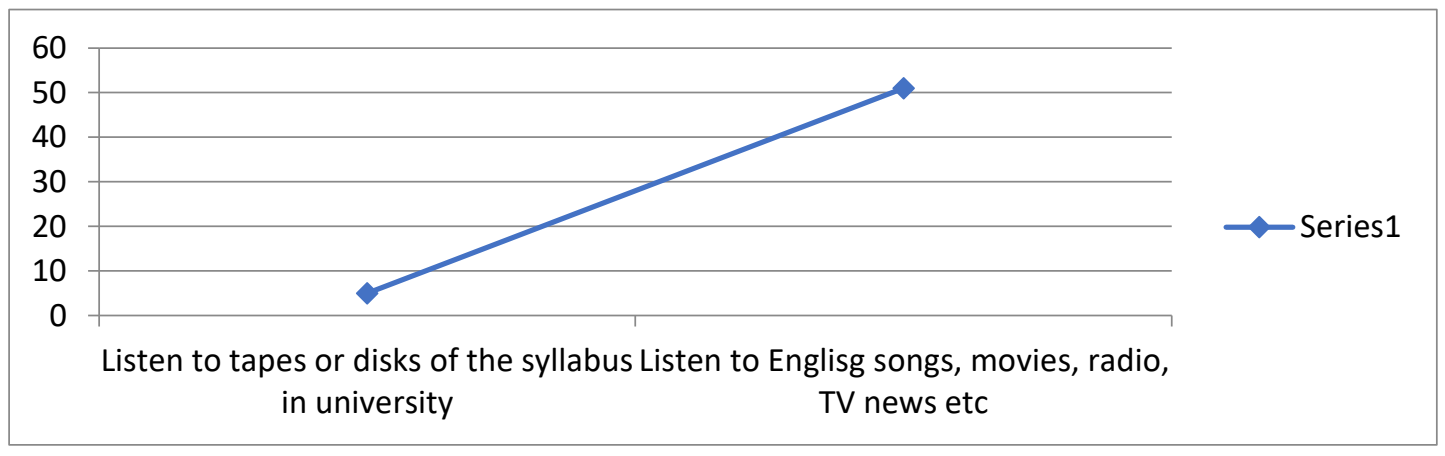

Figure 4. Chart Question 4 
It can be seen that 58 students learn listening outside classrooms by listening to English songs, movies, radio, TV news, etc. The other five students learn listening using other kinds of materials provided by the teacher. From the results of these questions, innovation is needed, both for the lecturers and the teaching material being taught. so that students have a good critical reading to be implemented in lectures, especially in a covid-19 pandemic situation. The conclusions in this study revealed that learning online increased knowledge and reading score gains.

\section{Discussion}

The critical reading strategy provides a set of critical reading strategies and practices related to several reading materials described previously in the form of individual practices and demonstrations through videos. Online use triggers their critical thinking through reading various sources. Online learning is more flexible and complements classroom learning due to limited space and learning hours (Almaiah et al., 2020; Hwang et al., 2012; Kuzmanović et al., 2019). In addition, online learning can facilitate different learning styles and conditions (Duncan et al., 2013; Mpungose, 2021). Online learning can take advantage of further possibilities that will benefit learning. However, online learning still requires face-to-face interaction for several reasons. Facilitates direct and intense personal interactions that online learning does not accommodate.

Reading comprehension is a complex cognitive activity that involves many interrelated processes (Creed et al., 2012; Kemp, 2017). Comprehension of printed texts requires word recognition, sentence processing, strategic processing, activation of relevant background knowledge, interpretation of meaning, and continuous monitoring of ongoing understanding (Gusliati et al., 2019; Maryani et al., 2017). The process can be refined through extensive reading. Developing critical literacy skills in academic situations is becoming more critical for second or foreign language learners (Jang et al., 2021; Sverdlov et al., 2014). Reading academic texts is considered one of the essential skills that Foreign Language (EFL) students must master (Xiaoming et al., 2021; Yuzulia, 2020)

By applying this strategy, learners pay attention to unfamiliar words and do not ignore unfamiliar words in the text. Students should also have a pencil on hand so they can "annotate" their text. Students are also taught to make connections to other sources they have read about the topic. The last strategy is summarizing, which helps students self-correct by reading the text repeatedly, examining the topic sentence, identifying the main ideas, and connecting the parts. When they summarize, they can find and write down the main points of the text. Summarizing allows participants to analyze and critique the original text. The role of the Polsri Learning Management System has been very helpful for students, but it needs to be balanced with innovative material content that persuasively increases student power to understand how critical reading is in a lesson.

\section{CONCLUSION}

It is concluded that reading is a complex process and teachers must shift to new strategies of reading online. The conclusions in this study revealed that learning online increased knowledge and reading score gains. It is suggested that the students explore their reading strategies and teachers should facilitate a conducive atmosphere to grow critical thinking as part of reading activities.

\section{REFERENCES}

Akın, F., Koray, Ö., \& Tavukçu, K. (2015). How Effective is Critical Reading in the Understanding of Scientific Texts? Procedia - Social and Behavioral Sciences, 174. https://doi.org/10.1016/j.sbspro.2015.01.915

Almaiah, M. A., Al-Khasawneh, A., \& Althunibat, A. (2020). Exploring the critical challenges and factors influencing the E-learning system usage during COVID-19 pandemic. Education and Information Technologies, 25(6), 5261-5280. https://doi.org/10.1007/s10639-020-10219-y

Anitha Kumari, T., Hemalatha, C. H., Subhani Ali, M., \& Naresh, R. (2020). Survey on impact and learning's of the online courses on the present era. Procedia Computer Science, 172, 82-91. https://doi.org/10.1016/j.procs.2020.05.167

Ariani, T. (2020). Analysis of Students' Critical Thinking Skills in Physics Problems. Physics Educational Journal, 3(1), 1-13. https://doi.org/10.37891/kpej.v3i1.119

Borre, Bernhard, Bleiker, \& Winsler. (2019). Preschool Literacy Intervention for Low-Income , Ethnically Diverse Children: Effects of the Early Authors Program Through Kindergarten Preschool Literacy Intervention for Low-Income. Journal of Education for Students Placed at Risk (JESPAR), 24(2). https://doi.org/10.1080/10824669.2019.1594818

Cahyadi, A. (2020). Covid-19 Outbreak and New Normal Teaching in Higher Education: Empirical Resolve from Islamic Universities in Indonesia. Dinamika Ilmu, 20(2), 255-266. https://doi.org/10.21093/di.v20i2.2545 
Cloonan, M. R., Cloonan, D. J., Schlitzkus, L. L., \& Fingeret, A. L. (2020). Learners with Experience in Surgical Scrub Benefit from Additional Education with an Interactive E-Learning Module. Journal of the American College of Surgeons, 4(2). https://doi.org/10.1016/j.jamcollsurg.2020.08.521

Creed, P. A., Conlon, E. G., \& Zimmer-Gembeck, M. J. (2012). Career barriers and reading ability as correlates of career aspirations and expectations of parents and their children. Journal of Vocational Behavior, 70(2). https://doi.org/10.1016/j.jvb.2006.11.001

Din, M. (2020). Evaluating university students' critical thinking ability as reflected in their critical reading skill: A study at bachelor level in Pakistan. Thinking Skills and Creativity, 35. https://doi.org/10.1016/j.tsc.2020.100627

Djalante, R., Lassa, J., Setiamarga, D., Sudjatma, A., Indrawan, M., Haryanto, B., Mahfud, C., Sinapoy, M. S., Djalante, S., Rafliana, I., Gunawan, L. A., Surtiari, G. A. K., \& Warsilah, H. (2020). Review and analysis of current responses to COVID-19 in Indonesia: Period of January to March 2020. Progress in Disaster Science, 6, 100091. https://doi.org/10.1016/j.pdisas.2020.100091

Duncan, M. J., Smith, M., \& Cook, K. (2013). Implementing online problem based learning (PBL) in postgraduates new to both online learning and PBL: An example from strength and conditioning. Journal of Hospitality, Leisure, Sport and Tourism Education, 12(1), 79-84. https://doi.org/10.1016/j.jhlste.2012.11.004

Fernández-Gutiérrez, M., Gimenez, G., \& Calero, J. (2020). Is the use of ICT in education leading to higher student outcomes? Analysis from the Spanish Autonomous Communities. Computers and Education, 157, 103969. https://doi.org/10.1016/j.compedu.2020.103969

Fu, Q. K., \& Hwang, G. J. (2018). Trends in mobile technology-supported collaborative learning: A systematic review of journal publications from 2007 to 2016. Computers and Education, 119(July 2017), 129-143. https://doi.org/10.1016/j.compedu.2018.01.004

Geng, S., Law, K. M. Y., \& Niu, B. (2019). Investigating self-directed learning and technology readiness in blending learning environment. International Journal of Educational Technology in Higher Education, 16(1), 17. https://doi.org/10.1186/s41239-019-0147-0

Gusliati, P., Eliza, D., \& Hartati, S. (2019). Analisis Video Pembelajaran Share Book Reading Menggunakan Cerita Rakyat Sabai Nan Aluih pada Anak Usia Dini. Jurnal Obsesi, 3(2). https://doi.org/10.31004/obsesi.v3i2.176

Haromi, F. A. (2014). Teaching through Appraisal: Developing Critical Reading in Iranian EFL Learners. Procedia - Social and Behavioral Sciences, 98(6). https://doi.org/10.1016/j.sbspro.2014.03.398

Hashimoto, T., Hayashi, Y., \& Seta, K. (2019). Metacognitive Inference Activity Support by Visualizing EyeMovement Graph During Critical Reading. Procedia Computer Science, 159. https://doi.org/10.1016/j.procs.2019.09.372

Heidari, K. (2020). Critical thinking and EFL learners' performance on textually-explicit, textually-implicit, and script-based reading items. Thinking Skills and Creativity, 37. https://doi.org/10.1016/j.tsc.2020.100703

Hochweber, J., \& Vieluf, S. (2018). Gender differences in reading achievement and enjoyment of reading: The role of perceived teaching quality. Journal of Educational Research, 111(3), 268-283. https://doi.org/10.1080/00220671.2016.1253536

Hogan, R., \& Devi, M. (2019). A synchronous pedagogy to improve online student success. International Journal of Online Pedagogy and Course Design, 9(3), 61-77. https://doi.org/10.4018/IJOPCD.2019070105

Hwang, G. J., Wu, P. H., \& Chen, C. C. (2012). An online game approach for improving students' learning performance in web-based problem-solving activities. Computers and Education, 59(4), 1246-1256. https://doi.org/10.1016/j.compedu.2012.05.009

Jang, M., Aavakare, M., Nikou, S., \& Kim, S. (2021). The impact of literacy on intention to use digital technology for learning: A comparative study of Korea and Finland. Telecommunications Policy, 45(7). https://doi.org/10.1016/j.telpol.2021.102154

Kadafi, A., Alfaiz, A., Ramli, M., Asri, D. N., \& Finayanti, J. (2021). The impact of islamic counseling intervention towards students' mindfulness and anxiety during the covid-19 pandemic. Islamic Guidance and Counseling Journal, 4(1), 55-66. https://doi.org/10.25217/igcj.v4i1.1018

Karasmanaki, E., \& Tsantopoulos, G. (2021). Impacts of social distancing during COVID-19 pandemic on the daily life of forestry students. Children and Youth Services Review, 120(December 2020), 105781. https://doi.org/10.1016/j.childyouth.2020.105781

Kemp, S. E. (2017). RAP: A reading comprehension strategy for students with learning disabilities and concomitant speech language impairments or ADHD. Journal of Education and Training, 4(2). https://doi.org/10.5296/jet.v4i2.11614

Khan, F. M. A., \& Masood, M. (2015). The Effectiveness of an Interactive Multimedia Courseware with Cooperative Mastery Approach in Enhancing Higher Order Thinking Skills in Learning Cellular 
Respiration. Procedia - Social and Behavioral Sciences, 176, 977-984. https://doi.org/10.1016/j.sbspro.2015.01.567

Komalasari, K., \& Rahmat, R. (2019). Living Values Based Interactive Multimedia in Civic Education Learning. International Journal of Instruction, 12(1), 113-126. https://doi.org/10.29333/iji.2019.1218a

Kuzmanović, M., Andjelković-Labrović, J., \& Nikodijević, A. (2019). Designing e-learning environment based on student preferences: Conjoint analysis approach. International Journal of Cognitive Research in Science Engineering and Education, 7(3), 37-47. https://doi.org/10.5937/ijcrsee1903037k

Lai, A. F., Chen, C. H., \& Lee, G. Y. (2019). An augmented reality-based learning approach to enhancing students' science reading performances from the perspective of the cognitive load theory. British Journal of Educational Technology, 50(1), 232-247. https://doi.org/10.1111/bjet.12716

Lawrence, J. E., \& Tar, U. A. (2018). Factors that influence teachers' adoption and integration of ICT in teaching/learning process. Educational Media International, 55(1), 79-105. https://doi.org/10.1080/09523987.2018.1439712

Liao, S., Hong, J.-C., Wen, M.-H., Pan, Y.-C., \& Wu, Y.-. (2018). Applying Technology Acceptance Model (TAM) to explore Users' Behavioral Intention to Adopt a Performance Assessment System for E-book Production. EURASIA Journal of Mathematics, Science and Technology Education, 14(10). https://doi.org/10.29333/ejmste/93575

Maryani, N., Ichsan, M., \& Khairunnisa. (2017). Signifikansi Metode Guide Reading Terhadap Motivasi Belajar Siswa Dalam Teori Membaca Nyaring Guide Reading Method On Students ' Learning Motivation In Reading Loudly Lesson. Didaktika Tauhidi: Jurnal Pendidikan Guru Sekolah Dasar, 4(2), 126-139. https://doi.org/10.30997/dt.v4i2.924

McGarr, O., \& Gallchóir, C. Ó. (2021). Examining supervising field instructors' reporting and assessment of technology use by pre-service teachers on school placement. Computers \& Education, 146. https://doi.org/10.1016/j.compedu.2019.103753

Memiş, A. D., \& Kandemir, H. (2019). The Relationship Between the Study Habits and Attitudes and Metacognitive Reading Comprehension Self-Awareness, Reading Comprehension, Reading Attitudes. World Journal of Education, 9(4), 133. https://doi.org/10.5430/wje.v9n4p133

Moghadam, Z. B., Narafshan, M. H., \& Tajadini, M. (2021). Development of a Critical Self in the Language Reading Classroom: An examination of Learners' L2 Self. Thinking Skills and Creativity, 3. https://doi.org/10.1016/j.tsc.2021.100944

Mpungose, C. B. (2021). Lecturers' reflections on use of Zoom video conferencing technology for e-learning at a South African university in the context of coronavirus. African Identities. https://doi.org/10.1080/14725843.2021.1902268

Primamukti, A. D., \& Farozin, M. (2018). Utilization of interactive multimedia to improve learning interest and learning achievement of child. Jurnal Prima Edukasia, 6(2), 111-117. https://doi.org/10.21831/jpe.v6i2.19183

Reilly, C. A. (2021). Reading risk: Preparing students to develop critical digital literacies and advocate for privacy in digital spaces. Computers and Composition, 61. https://doi.org/10.1016/j.compcom.2021.102652

Rhim, H. C., \& Han, H. (2020). Teaching online: foundational concepts of online learning and practical guidelines. Korean Journal of Medical Education, 32(3), 175-183. https://doi.org/10.3946/kjme.2020.171

Roosa, K., Lee, Y., Luo, R., Kirpich, A., Rothenberg, R., Hyman, J. M., Yan, P., \& Chowell, G. (2020). Realtime forecasts of the COVID-19 epidemic in China from February 5th to February 24th, 2020. Infectious Disease Modelling, 5, 256-263. https://doi.org/10.1016/j.idm.2020.02.002

Rubini, B., Permanasari, A., \& Yuningsih, W. (2018). Learning Multimedia Based on Science Literacy on the Lightning Theme. Jurnal Penelitian Dan Pembelajaran IPA, 4(2), 89-104. https://doi.org/10.30870/jppi.v4i2.3926

Saprudin, S., Liliasari, L., Prihatmanto, A. S., \& Setiawan, A. (2019). The Potential of Gamification in Developing Pre-Service Physics Teachers' Critical and Creative Thinking Skills. Omega: Jurnal Fisika Dan Pendidikan Fisika, 5(1), 167-171. https://doi.org/10.31758/omegajphysphyseduc.v5i1.7

Seibert, S. A. (2020). Problem-based learning: A strategy to foster generation Z's critical thinking and perseverance. Teaching and Learning in Nursing, 000, 2-5. https://doi.org/10.1016/j.teln.2020.09.002

Shastina, E. M., Jentgens, S., Shatunova, O. V., Borisov, A. M., \& Bozhkova, G. N. (2020). Role of literary pedagogy in modern education of preschool and primary school children. Space and Culture, 8(1), 234243. https://doi.org/10.20896/saci.v8i1.795

Stover, K., Yearta, L., \& Harris, C. (2016). Experiential Learning for Preservice Teachers: Digital Book Clubs With Third Graders. Journal of Digital Learning in Teacher Education, 32(1), 5-12. https://doi.org/10.1080/21532974.2015.1055013

Sverdlov, A., Aram, D., \& Levin, I. (2014). Kindergarten teachers' literacy beliefs and self-reported practices: 
On the heels of a new national literacy curriculum. Teaching and Teacher Education, 39. https://doi.org/10.1016/j.tate.2013.12.004

Talebi, M., \& Marzban, A. (2015). The Effect of Teaching Critical Reading Strategies on Advanced Iranian EFL Learners' Vocabulary Retention. Theory and Practice in Language Studies, 5. https://doi.org/10.17507/tpls.0503.17.

Utami, T. N., Jatmiko, A., \& Suherman, S. (2018). Pengembangan Modul Matematika dengan Pendekatan Science, Technology, Engineering, And Mathematics (STEM) pada Materi Segiempat. Desimal: Jurnal Matematika, 1(2), 165. https://doi.org/10.24042/djm.v1i2.2388

Xiaoming, Zhang, L. J., \& Dixon, H. R. (2021). Implementing Assessment for learning (AfL) in Chinese university EFL classes: Teachers' values and practices. System, 10. https://doi.org/10.1016/j.system.2021.102589

Yuzulia, I. (2020). EFL tecahers' perceptions and stratgeies in inplementing learner autonomy. Journal of Linguistics and Language Teaching, 6(1), 36-54. https://doi.org/10.29300/ling.v6i1.2744 